\title{
Internationalization and Multiple Discrimination: the Case of Employment Regulation
}

\author{
Raimonda Bublienè \\ Department of Business Management, Vilnius Gediminas Technical University, Vilnius, Lithuania \\ Institute of International and European Union Law, Mykolas Romeris University, Vilnius, Lithuania \\ E-mails: raimonda.bubliene@vgtu.lt; rabubliene@stud.mruni.eu
}

Received 14 February 2017; accepted 07 April 2017

\begin{abstract}
The article analyses European Union anti-discrimination law development in Member States and differences between protected grounds of discrimination. On this basis, the analysis covers recognition of the social complexity, internationalization and discrimination of foreigners for different grounds. The process of internationalization and migration, covering social, political, economical, cultural, legal processes, the non-discriminatory protection of a foreigner as a member of the society has become complicated, when attempting not to discriminate people arriving from the other countries and to have equal possibilities. The problems of discrimination are valid and significant for the civil society itself. The article also discusses the concept of multiple discrimination in European Union anti-discrimination law, legal regulation and protection against multiple discrimination in Europe and separate legal regulation of the Member States. This article argues that internationalization processes bring new approaches of interpretation of European Union employment equality law and contemporary challenges, introduces recent cases of equal treatment of employees during employment at private companies.
\end{abstract}

Keywords: discrimination, multiple discrimination, equal treatment, employment equality law, discrimination law, labor market discrimination.

JEL Classification: K380, J700, J710.

Conference topic: Internationalization Processes: Contemporary Challenges.

\section{Introduction}

During the process of the total globalization and internationalization of the modern world the increase of migration has become very significant as well as the related changes possessing migratory character, observable in the society at present. The growing scopes of migration in the countries of Europe determine the regulation of the constantly changing legal status of foreigners as well. The migration factors are closely related to the status of foreigners in the society as well as they ensure and safeguard the rights of foreigners as well as non-discrimination.

European Union (EU) equality and anti-discrimination law was developing during the last fifty years in Europe. Further to the introduction of ex-Article 13 Treaty establishing the European Community (TEC) (2002) by the Amsterdam Treaty (now Article 19 Treaty on the Functioning of the European Union (TEFU) (2012)) two directives banned prohibition of employment discrimination for five grounds of racial or ethics origin, religion or belief, age, disability and sexual orientation came into effect from 2000.

The Racial Equality Directive (2000) and Employment Equality Directive (2000) defined the existing approaches of discrimination based on racial or ethnic origin, religion or belief, disability, age and sexual orientation around the Europe and ensured that all people living in the European Union could benefit from effective legal protection for named grounds against the discrimination, irrespective of their nationality. On the other hand, having in mind that enforcement of EU equality law at national level remains problematic, some argue that, in the next years, the EU focus should not to be on generating more legislation and institutions, but rather on improving the existing ones (Givens, Case 2014).

The legal acts of the European Union prohibit discrimination; however, the multiple discrimination has not been determined so far there. The exclusive status of foreigners in the society creates preconditions for discrimination to be developed and therefore discrimination tends to be expressed by more than one aspect.

The legal acts of the EU are aimed to ensure non-discrimination, but the safeguarding against discrimination based on various reasons is considered to be much wider than discrimination caused by some other reasons (e.g. better 
protection is ensured concerning race and ethnic origin, gender, if compared with the other causes). The advent of the national and international case law, when focusing on a single cause, is not adequate enough to solve the phenomenon of multiple discrimination, in the context of law on anti-discrimination of foreigners. Multiple discrimination and its manifestations in the society have been insufficiently investigated so far. The purpose of the article is to identify the internationalization and legal regulation of the multiple discrimination, employment equality regulation in Europe.

\section{Developing anti-discrimination law in Europe}

The Member States of the EU are required to ensure that the national legislation has to comply with the directive requirements and to make all changes of the national legal regulation that are needed. The Racial Equality Directive (2000) requires Member States to prohibit the following forms of discrimination: direct and indirect discrimination, harassment and instructions to discriminate on the grounds of ethnic or racial origin. That prohibition of discrimination includes employment, self-employment, self-employment and occupation, vocational training, social protection covers social security and healthcare, education and access to and supply of goods and services available to the public including housing.

The Employment Equality Directive (2000) covers the protection given to the field of employment and occupation as well as vocational training on the grounds of age, religion or belief, sexual orientation and disability, prohibits indirect and direct discrimination as well as harassment and instructions to discriminate, it is applied only in the sphere of employment. EU equality law and the fields covered by European Union legislation for the grounds of discrimination as age, disability, religion or belief, sexual orientation, sex, race ethnic origin disposed at Table 1 (see Table 1).

Table 1. Antidiscrimination coverage in EU legislation (Source: Bąkowski, Copeland 2012)

\begin{tabular}{|c|c|c|c|c|c|c|c|}
\hline & \multirow{2}{*}{$\begin{array}{c}\text { Patchwork in EU } \\
\text { equality law }\end{array}$} & \multicolumn{6}{|c|}{ Grounds of Discrimination } \\
\hline & & Age & Disability & $\begin{array}{c}\text { Religion or } \\
\text { Belief }\end{array}$ & $\begin{array}{c}\text { Sexual } \\
\text { Orientation }\end{array}$ & Sex & $\begin{array}{l}\text { Race, Ethnic } \\
\text { Origin }\end{array}$ \\
\hline \multirow{4}{*}{ 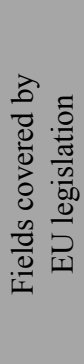 } & Education & NO & NO & NO & NO & NO & YES \\
\hline & Social Protection & NO & NO & NO & NO & $\begin{array}{l}\text { PARTLY } \\
\text { COVERED }\end{array}$ & YES \\
\hline & Social Advantages & NO & NO & NO & NO & $\begin{array}{l}\text { PARTLY } \\
\text { COVERED }\end{array}$ & YES \\
\hline & $\begin{array}{l}\text { Access to Goods and Services } \\
\text { available to the Public, } \\
\text { including Housing }\end{array}$ & NO & NO & NO & NO & YES & YES \\
\hline
\end{tabular}

The European Union's undertaking of non-discrimination principle was approved in the Charter of Fundamental Rights of the European Union (2010) in December 2000. Article 21 of the Charter of Fundamental Rights of the European Union (2010) confirms that any discrimination based on any ground such as sex, race, colour, ethnics or social origin, genetic features, language, religion, or belief, political or any other opinion, membership of a national minority, property, birth, disability, age or sexual orientation shall be prohibited: "Any discrimination based on any ground such as sex, race, colour, ethnic or social origin, genetic features, language, religion or belief, political or any other opinion, membership of a national minority, property, birth, disability, age or sexual orientation shall be prohibited. Within the scope of application of the Treaties and without prejudice to any of their specific provisions, any discrimination on grounds of nationality shall be prohibited".

According to Article 258 of the Treaty on the Functioning of the European Union (2012), infringement proceedings against Member State maybe imposed by the European Commission, by failing to transfer the Racial Equality Directive (2000) or the Employment Equality Directive (2000), it considers to have failed to fulfil their Treaty obligations: "if the Commission considers that a Member State has failed to fulfil an obligation under the Treaties, it shall deliver a reasoned opinion on the matter after giving the State concerned the opportunity to submit its observations. If the State concerned does not comply with the opinion within the period laid down by the Commission, the latter may bring the matter before the Court of Justice of the European Union".

Charter of Fundamental Rights of the European Union (2010) (Charter) has launched the codification stage of the new Fundamental Right on the protection of the rights in the EU. Charter only applies in the implementation of EU law by EU institutions and Members States. Charter has obtained the same legal value as the agreements and has been assigned to the Primary Law although it has not been directly integrated into the Treaties, but has comprised a separate document. Charter is based on the European Convention on the Human Rights (1950) (ECHR), on the provisions of the European Social Charter (1961) and the other conventions on the human rights, on the general constitutional tradition of the EU Member States. 
Based on Article 13 of the Treaty establishing the European Community (2002) there has been provided a basic extended list on discrimination where the preconditions for starting a legal proceeding regarding discrimination under the basis of more than one aspect of discrimination have been drawn up, the Council was authorized on acting united with the Commission and the European Parliament to contend discrimination that based on racial or ethnic origin, religion or belief, disability, age, sex or sexual orientation.

Even though the Employment Equality Directive (2000), and Racial Equality Directive (2000), have applied the term of multiple discrimination and in the preamble of the directives there has been consolidated the relation of the provided fundamental, regarding race, however the conception of multiple discrimination in the mentioned above directives has not been revealed yet.

The transposition of the Racial Equality (2000) and Employment Equality (2000) Directives has remarkably consolidated legal protection and anti-discrimination on the grounds of racial and ethnic origin, religion and belief, age, disability and sexual orientation across the Europe. Traditionally anti-discrimination law sees in the singular race or religion or disability and after the complaining separate proof is required for every ground.

Multiple discrimination has not been specifically recognized and there have been no provisions made so far in the legislation of the EU or majority of Member States. The analysis of the problems regarding the experienced discrimination in the EU, is valuable from the point of view of social and economical factors, because it might motivate the victims suffering from discrimination to protect their own rights which have been violated.

The victims of multiple discrimination and the lawyers protecting them might expect to have the possibility to appeal to court with lawsuits more frequently as well as the lawsuits dealing with the damages awarded due to multiple discrimination might be higher in monetary value than the lawsuits dealing with discrimination based on a single factor. The European Union is based on equality, which requires avoiding any kind of discrimination against a person based on certain personal characteristics, peculiarities or personal identity.

\section{Internationalization and protection from multiple discrimination in Europe}

The law of regulation of foreigners under the influence of modern globalization in any country appears to be very significant from the point of view of domestic and foreign policy. The proper Schengen space surveillance is considered to be one of the most prioritized goals of the modern EU, which serves the space of freedom, safety and justice, where free movement of persons is ensured as well as freedom and human rights are respected, the processes of migration are regulated in accordance with the requirements of the EU, all the issues related to the policy of migration are solved.

The legal Acts of the Republic of Lithuania (LR) are constantly improved in order to solve all the related problems. The primary source of the national law of LR, adjusting the regulatory legal status of aliens is the Republic of Lithuania Law on the Legal Status of Aliens (2004). The latest amendments to the law are related to such aliens who intend to obtain residence permits in Lithuania based on their legitimate employment, on their status, on the assessment of setting up business and on the fictitiously owned enterprises, on the requirements related to the living space allocated for them and due to the other changes concerning their labour activities and studies in Lithuania.

Republic of Lithuania Law on the Legal Status of Aliens (2004) Article 3 concerning the legal status of foreigners differs the rights and duties for aliens in the LR:

1. Aliens in the Republic of Lithuania shall enjoy the rights and freedoms provided for by the Constitution of the Republic of Lithuania, international treaties, laws of the Republic of Lithuania and legal acts of the European Union.

2. Aliens in the Republic of Lithuania shall be equal before the law, irrespective of their sex, race, nationality, language, origin, social status, religion, convictions or views.

3. Aliens in the Republic of Lithuania must observe the Constitution of the Republic of Lithuania, laws and other legal acts of the Republic of Lithuania.

4. At the request of officers of the police or any other law enforcement institution, aliens must produce documents confirming their identity (travel document, residence permit or any other document) as well as other documents specifying the purpose and conditions of their stay in the country and attesting to the lawfulness of an alien's stay in the Republic of Lithuania.

The principal of non-discrimination itself has been consolidated on the national and international level, but in the social context of the society the conception of discrimination itself has been expanded, the new forms of discrimination have appeared, namely multiple discrimination has originated as one of them. However, the phenomenon of multiple discrimination has been specifically recognized neither in the EU nor in the legal acts among the majority of the Member States, even though the sources of the multiple discrimination could be observed at the end of the 19th century, when African American women in the USA provoked the issue of their identity and it has happened for the lingering impact of slavery on the American labour market (Solanke 2010).

African American women workers were inevitably the last to be hired in jobs, treated as the less important workers and they were always the first to be fired. Five African American women, who were employed for around six months and fired, were charged by General Motors for the intersectional discrimination (sex and race). Intersectional discrimination was experienced as well for the employer's decisions that black women workers cannot take specific roles for management duties or client facing, employers refused to give a position to a black woman and granted a role to a white woman or black man. 
During the recent years it has become obvious that it is incorrect to assess all the cases of discrimination based on the only factor or characteristics. The reality is the following. The majority of people have experienced discrimination based on several fundamentals (Ellis, Watson 2012).

The problems arise under the influence of different factors. S. Hannett has determined the diverse forms of multiple discrimination, such as additive or cumulative discrimination and intersectional one.

Multiple discrimination is considered to be one of the three forms (Hannett 2003):

- cumulative multiple discrimination is considered to be such a situation when a person is valued less favourably for more than one ground, but each type of discrimination is caused by different circumstances (see Fig. 1);

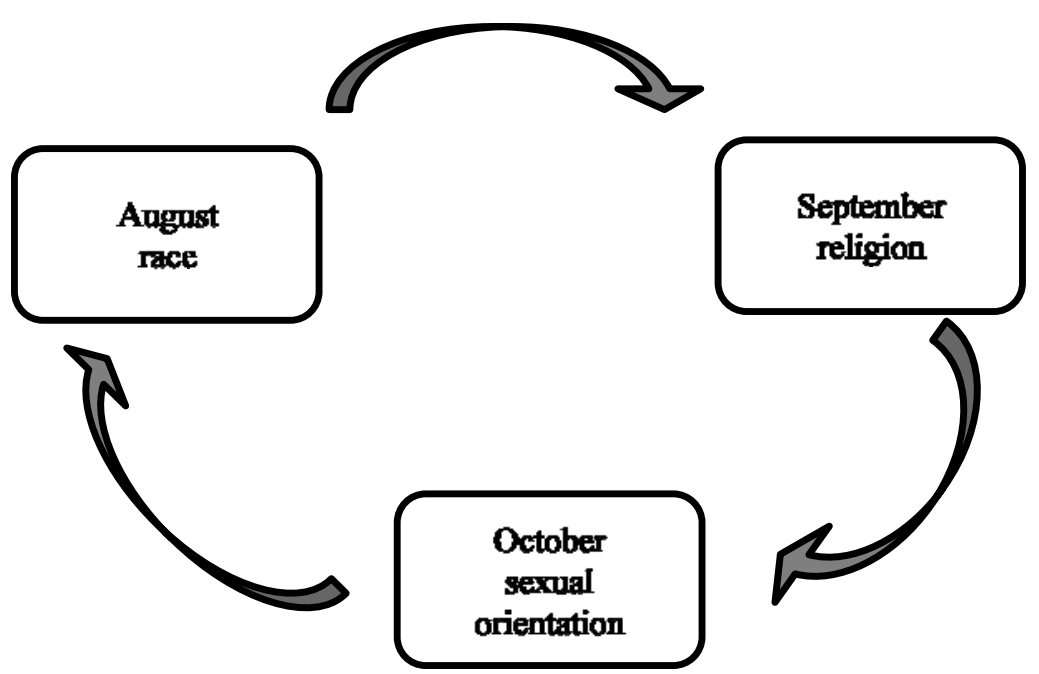

Fig. 1. Cumulative Multiple Discrimination (Source: composed by the author)

- additive multiple discrimination is considered in cases when a person is valued less favourably based on more than one protected characteristics and even though two autonomous forms of discrimination tend to appear there, they are not related in between (see Fig. 2);

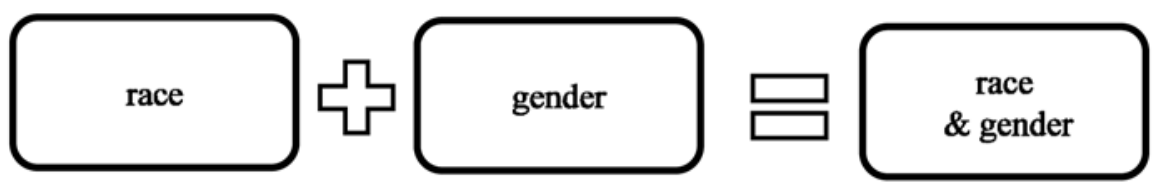

Fig. 2. Additive Multiple discrimination (Source: composed by the author)

- intersectional multiple discrimination is related to the unique inseparable combination of the characteristics, which appear to serve the causes of the stereotypes. It is possible to state, that there exist the stereotypes which according to the definition relate the characteristics. Synergy is specific for the intersectional multiple discrimination when two separate factors acting together give a positive higher impact than the sum of the impacts of both factors acting separately (see Fig. 3).

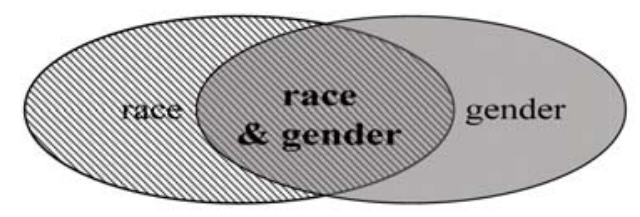

Fig. 3. Intersectional discrimination (Source: composed by the author)

Multiple discrimination is significant and that has been proved by the studies of the European Commission as well as the submitted report dealing with the movement against the multiple discrimination (European Commission 2007). Despite the regional framework, the overwhelming majority of legal systems in Europe are silent regarding multiple discrimination. No legal regulation in Liechtenstein Cyprus, Denmark, Finland, France, Hungary, Iceland, 
Ireland, Italy, Estonia, Latvia, Lithuania, the Czech Republic, The Netherlands, Norway, Malta, Poland, Portugal, Slovakia, and Slovenia does not provide any explicit condition and have no intention to regulate this.

In some countries there is no legislation but multiple discrimination is declared by the courts as the judicial recognition. Courts in France have recognized cumulative multiple discrimination without the setting it in the law. Latvian district court found multiple discrimination for the grounds of gender and property status-based discrimination. Some other European countries legal systems constitute a clear mention of multiple discrimination, unfortunately there is no definition only very basic descriptive statement that are not encouraged with the details. It is necessary to clarify the international and regional framework of the legislation of multiple discrimination that may impact further significant appearance of the legal regulation of multiple discrimination in domestic law.

The United Kingdom is considered to be the first Member State in the EU that has declared multiple discrimination in the Act of the National Legislation and approved the Equality Act (2010). It prescribes the cause of multiple discrimination, namely when a person (A) discriminates another person (B), based on merging of two connected and protected characteristics, in case when the treatment of A person towards B person has been less appropriate then the treatment of A person or the treatment regarding the other person who has not obtained any prescribed characteristics. The definition mentioned above does not require from the plaintiff, who considers that he has suffered the discrimination under the basis of more than one reason, to prove it as discrimination under each case. It is not required for person B to prove that the treatment of person A towards him is to be considered as a direct discrimination caused by each of these characteristics in the combination (taken alone).

The legal act also prescribes the obligatory exemption from the specific requirements, e.g. in case a husband makes an appeal against the refusal to be recruited because of one's disability or the employer proves that the vacant position requires a necessary professional experience for that particular work or namely the authorities require a female sex there instead. Multiple discrimination is not regarded in the above mentioned case, because discrimination based on gender has been already authorized but there have been no reasons for considering the discrimination to be based on disability (Equality Act 2010).

The indiscrimination of aliens in the society is closely related to the tolerance prevailing in the society as well as the ability to welcome and integrate them. It should be noted that in program 'HORIZON 2020' (European Commission 2014), approved by the Commission of the EU, dealing with the most extensive program on the scientific research and innovations in the EU, then a very particular attention has been paid in terms of the society of the EU which is expected to be inclusive, innovative, positively reasoning as well as tolerant. The program prescribes the priority to underline European society challenges, which have to be faced under the changing world. The principal target to be able to achieve is considered to be the formation of the reasonable and thinking society, where the common values are significant and they are considered to serve the input for the common future goals to be accomplished (European Commission 2014).

The branch of anti-discrimination law is relevant and thus, there are discussed the issues in relation to the motives and forms causing multiple discrimination as well as the problems of regulating and adjusting discrimination as well as the perspectives of proposal for a Council Directive on implementing the principle of equal treatment between persons irrespective of religion or belief, disability, age or sexual orientation, 'Horizontal Directive' (2008).

The 'Horizontal Directive' has to pursue and implement the principle of the same equal approach towards any person regardless of their religion or beliefs, age or sexual orientation. Moreover, after the approval of the directive it is likely that any problem regarding 'hierarchy of motives for discrimination' has to be eliminated and only then the problems concerning multiple discrimination could be solved more effectively when applying the national laws in any Member State.

After having assessed the above mentioned circumstances it is possible to state that the unique combination of characteristics is applicable for a foreigner residing in a 'host' cultural and social society when based on the personal performance or under certain circumstances, the individuality of which causes discrimination under more than one factor.

The greatest threat could be caused in case the factors of discrimination could be based on ethnic, national, religious or any other factor as well as due to the lack of tolerance, advanced prejudices in cases when aliens could be segregated by the local authorities and communities. According to the author, foreigners comprise a certain part of the society which tends to appear in the so called 'high risk group'. The demand for legal instruments when fighting against non-discrimination is great and inevitable, together with the constantly increasing impact of globalization on the society, which in one or another way tends to influence the migration flows in Europe as well as in all the rest of the world.

The legislation of the EU prohibits discrimination and at present in the law on anti-discrimination in the EU, there is missing the concept of multiple discrimination as it has not been consolidated yet. The EU legislation prohibits discrimination caused by the following six grounds, namely gender, age, disability, religion or beliefs, race or ethnic origin and sexual orientation. However, the EU legislation guarantees more favourable protection against race or ethnic origin, or gender discrimination in comparison to the other reasons. The ongoing discussion, concerning 'Horizontal directive' which started in 2008 and was initiated by the European Commission and which ensured equal protection against discrimination based on all the mentioned above factors, has been in progress. 


\section{Employment equality cases}

The progress of EU equality law in the last fifty years developed from a market right to a social and after that to fundamental right. The earliest application of the right to equal treatment at EU level was the principle of equal pay that refers to the Treaty on the Functioning of the European Union (2012) current Article 157 (1) (2) "Each Member State shall ensure that the principle of equal pay for male and female workers for equal work or work of equal value is applied. For the purpose of this Article, 'pay' means the ordinary basic or minimum wage or salary and any other consideration, whether in cash or in kind, which the worker receives directly or indirectly, in respect of his employment, from his employer. Equal pay without discrimination based on sex means: (a) that pay for the same work at piece rates shall be calculated on the basis of the same unit of measurement; (b) that pay for work at time rates shall be the same for the same job".

EU started to recognize equal treatment not only as a social right, as a fundamental right as well. EU equality directives The Racial Equality Directive (2000) and Employment Equality Directive (2000) are progressive evolution, which has led to progressive legislation and inconsistencies, the different protections levels afforded for different discrimination grounds (Watson 2009).

Recently two cases are in a process at Court of Justice of the European Union (CJEU) regarding the discrimination on the religion ground from the side of private employer Achbita v. G4S Secure Solutions NV and Bougnaoui and AADD v. Micropole Universe SA. Two women Achbita from Belgium and Bougnaoui from France were dismissed for wearing the hijab at work and the CJEU now has to address the issue of reasonable accommodation of religious diversity at the workplace. In both cases, the hijab was in conflict with the private companies' neutrality policies, but the important difference between that Bougnaoui had always worn the hijab and was only required not to wear it in the presence of clients and Achbita started to wear hijab after having been employed for around three years in the company and was not allowed to wear it at all.

The questions which the CJEU must answer, for the first time in the Achbita case, is a private company, private employer permitted to prohibit a female employee of Muslim religion to wear a headscarf in the workplace and to dismiss her if she refuses to remove the headscarf at work place, from the point of view of EU law, and prohibition of discrimination based on religion or belief at Employment Equality Directive (2000).

The opinions of Advocates General were proposed in both cases. It is important to mention that Advocate General's Opinion is not binding on the Court of Justice of the European Union and it is the role of the Advocates General to propose to the Court, in complete independence, a legal solution to the cases for which they are responsible.

In Achbita case the Advocate General Kokkot (2016) stated the following conclusion: "In the light of the foregoing submissions, I propose that the Court's answer to the request for a preliminary ruling from the Belgian Hof van Cassatie (Court of Cassation) should be as follows:

1) The fact that a female employee of Muslim faith is prohibited from wearing an Islamic headscarf at work does not constitute direct discrimination based on religion within the meaning of Article 2(2)(a) of Directive 2000/78/EC if that ban is founded on a general company rule prohibiting visible political, philosophical and religious symbols in the workplace and not on stereotypes or prejudice against one or more particular religions or against religious beliefs in general. That ban may, however, constitute indirect discrimination based on religion under Article 2(2) (b) of that directive.

2) Such discrimination may be justified in order to enforce a policy of religious and ideological neutrality pursued by the employer in the company concerned, in so far as the principle of proportionality is observed in that regard.

In that connection, the following factors in particular must be taken into account:

- the size and conspicuousness of the religious symbol,

- the nature of the employee's activity,

- the context in which she has to perform that activity, and

- the national identity of the Member State concerned".

In Bougnaoui case the Advocate General Sharpston (2016) stated the following conclusion: "The Advocate General therefore concludes that Ms Bougnaoui's dismissal constituted direct discrimination, to which none of the derogations provided for by the Directive apply. Finally, the Advocate General briefly considers the legal position should the present case be found to concern indirect discrimination, either because the Court of Justice disagrees with her when delivering judgment or because new matters of fact may subsequently be placed before the national court. The Advocate General observes that a company policy imposing an entirely neutral dress code is likely to result in indirect discrimination. Such a policy can be justified if it pursues a legitimate aim and is proportionate. A neutral dress code policy might be in the interests of the employer's business and therefore constitute a legitimate aim".

The central issue and questions asked by the national courts in both claims is whether the neutrality rule is indirectly discriminatory for religious employees who feel compelled to wear visible religious symbols and to explain under the EU law of indirect discrimination, there could be an undertaking for employers to reasonably accommodate the needs of employees of certain religious faiths, or companies' policies pursue a legitimate aim and proportional. 


\section{Conclusions}

Despite the extensive regulation of the anti-discriminatory legislation of the EU, the people in the whole EU tend to confront the obstacles, which prevent them from identifying their potentials in various situations of everyday life, the same applies for Lithuania as well. The anti-discriminatory legislation in the EU makes it possible for the victims of discrimination to complain to the relevant authorities, institutions, courts and etc. However, one must note, that upon the process of internationalization and migration, covering social, political, economical, cultural, legal processes, the non-discriminatory protection of a foreigner as a member of the society has become rather complicated, when attempting not to discriminate people arriving from the other countries and to have equal possibilities.

EU law making in terms of Anti-discrimination Law and the principal of Equal Possibility acknowledges that different grounds to be defended might intersect but there have not been adopted any regulation on the particular multiple discrimination. The specific regulation of the multiple discrimination could assist in perceiving the problem and at the same time in ensuring more efficient protection of any individual group (the citizens of the foreign countries included).

The Employment Equality Directive (2000) and Racial Equality Directive (2000) have accomplished a very significant role when qualifying its definition in terms of direct and indirect discrimination and have served the general perception of it; the definition determining multiple discrimination has also been considered to be significant for the approval of the general perception regarding manifold discrimination.

The EU legal acts ban discrimination based on to the following six grounds namely gender, age, disability, religion or beliefs, race or ethnic origin and sexual or gender orientation. However, in the legal acts of the EU there has been prescribed more favourable protection against discrimination based on race or ethnic origin and gender than on the other grounds. The common approach has not been promoted as well as equal possibilities for all the citizens in all the fields, especially the lack of attention has been indicated concerning the legal status and the uniqueness of foreigners; meanwhile persons have not been treated as the individuals of multiple identity.

The problems of discrimination are valid and significant for the civil society itself. Aliens comprise a social group, which potentially has to confront discrimination. They are the ones who most often face multiple discrimination. In communities, there is a constant insufficiency of knowledge about the multiple forms of discrimination and the particular kind of matter, due to the absence of specific acknowledgement of the phenomenon of multiple discrimination, both in European Union legislation and in the national legislation among the majorities of Member States.

Generally speaking, foreigners face discrimination; the fundamentals reviewed from the legal and doctrinal point of view are considered to be more complicated than it could be perceived at the first glance. This is true, that when two or more grounds merge they tend to have a general impact on a person; when separating the grounds the complex assessment of the caused damage is left behind. Therefore, further investigation is required in order to be able to determine and investigate the measures to be applied in cases of intersectional multiple discrimination; the methods have to be compared as well as the amount of the damage to be covered.

In the recent case of Achbita the Advocate General proposes a new and different analysis of the concept of direct discrimination and seeks to reduce the protection given to religion and belief under Employment Equality Directive (2000). It probably was caused by the migrant crisis that currently was created $g$ in certain parts of European societies. On the other hand, the freedom to conduct a business is a general principle of European Union law, it is subject to limitations, including the need to protect the rights and freedoms of others and the potential financial loss that might occur to the employer cannot be justified on the ground of direct discrimination.

\section{References}

Achbita v. G4S Secure Solutions NV. Case in process. Court of Justice of the European Union. Case No. C-157/15.

Advocate General's Opinion in Case C-157/15 Achbita v. G4S Secure Solutions NV. 2016. Court of Justice of the European Union. Case No. C-157/15.

Advocate General's Opinion in Case C-188/15 Bougnaoui and AADD v. Micropole Univers SA. 2016. Court of Justice of the European Union. Case No. C-188/15.

Bąkowski, P.; Copeland, N. 2012. The EU's role in combating discrimination [online], [cited 10 February 2017]. Available from Internet:

http://www.europarl.europa.eu/RegData/bibliotheque/briefing/2012/120299/LDM_BRI(2012)120299_REV2_EN.pdf

Bougnaoui and AADD v. Micropole Univers SA. Case in process. Court of Justice of the European Union. Case No. C-188/15.

Charter of Fundamental Rights of the European Union. 2010. Official Journal No. C 83/389.

Consolidated version of the Treaty on the Functioning of the European Union. 2012 Official Journal No. C 326.

Council Directive (EC) No. 2000/43/EC. Council Directive 2000/43/EC of 29 June 2000 implementing the principle of equal treatment between persons irrespective of racial or ethnic origin. 2000. Official Journal No. L 180.

Council Directive (EC) No. 2000/78/EC. Council Directive 2000/78/EC of 27 November 2000 establishing a general framework for equal treatment in employment and occupation. 2000. Official Journal No. L 303. 
Council Directive Proposal No. COM/2008/0426. Proposal for a Council Directive on implementing the principle of equal treatment between persons irrespective of religion or belief, disability, age or sexual orientation SEC(2008) 2180 SEC(2008) 2181. 2008. CNS 2008/0140.

Council of Europe. 1950. European Convention on Human Rights [online], [10 February 2017]. Available from Internet: http://www.echr.coe.int/Documents/Convention_ENG.pdf

Council of Europe. 1961. European Social Charter [online], [10 February 2017]. Available from Internet: $\mathrm{https}$ ://rm.coe.int/CoERMPublicCommonSearchServices/DisplayDCTMContent?documentId=090000168048b059

Ellis, E.; Watson, P. 2012. EU anti-discrimination law. Oxford: Oxford University Press. https://doi.org/10.1093/acprof:oso/9780199698462.001.0001

European Commission. 2014. HORIZON 2020 the EU Framework Programme for Research and Innovation [online], [10 February 2017]. Available from Internet: http://ec.europa.eu/programmes/horizon2020/en/area/society

Fredman, S. 2005. Double trouble: multiple discrimination and EU law, European Anti-Discrimination Law Review 2: $13-18$.

Givens, T. E.; Case, R. E. 2014. Legislation equality: the politics of antidiscrimination policy in Europe. Oxford: Oxford University Press. https://doi.org/10.1093/acprof:oso/9780198709015.001.0001

Hannett, S. 2003. Equality at the intersections: the legislative and judicial failure to tackle multiple discrimination, Oxford Journal of Legal Studies 23(1): 65-86. https://doi.org/10.1093/ojls/23.1.65

Republic of Lithuania law on the legal status of aliens. 2004. Valstybès žinios No. 73-2539.

Solanke, I. 2010. Multiple discrimination in Britain: immutability and its alternative [online], [10 February 2017]. Available from Internet: http://www.eracomm.eu/oldoku/Adiskri/11_Multiple_discrimination/2010_09_Solanke_EN.pdf

Treaty establishing the European Community. 2002. Official Journal No. C 325.

Watson, P. 2009. EU social and employment law: policy and practice in an enlarge Europe. Oxford: Oxford University Press. 